\title{
PENGARUH KEPEMIMPINAN, KOMUNIKASI DAN DISIPLIN KERJA TERHADAP KINERJA PEGAWAI DINAS PENDIDIKAN, PEMUDA DAN OLAHRAGA KABUPATEN BIREUEN
}

\author{
Khairul Mursalin ${ }^{1)}$ dan Kamaruddin ${ }^{2 *}$ \\ ${ }^{1}$ Pegawai Disdikpora Kabupaten Bireuen \\ ${ }^{2}$ Dosen FE Universitas Almuslim Peusangan Bireuen \\ *) email: kamal@uniki.ac.id psmm.uniki@gmail.com
}

DOI:

https://doi.org/10.55178/idm.v2i3.213

\section{ABSTRAK}

Article history

Received:

March 12, 2021

Revised:

March 15, 2021

Accepted:

March 19, 2021

Page:

$42-51$

Kata kunci:

Leadership,

Communication

Work Discipline

Performance
The research was conducted on employees of the Education, Youth and Sports Office of Bireuen Regency 1). Knowing the influence of leadership on employee performance, 2). Knowing the effect of communication on employee performance, 3). Knowing how the influence of work discipline on employee performance, and 4). Knowing the influence of leadership, communication and work discipline on the performance of the employees of the Education, Youth and Sports Office of Bireuen Regency. This research is a quantitative research with a survey of 78 employees with data collection through questionnaires. And the method of data analysis with statistics with a path analysis approach. The results showed that a) There is a direct and indirect effect of leadership on employee performance by $18.85 \%$. b) There is a direct and indirect effect of communication on employee performance by $21.04 \%$. c) There is a direct and indirect effect of work discipline on employee performance by $23.5 \%$. Based on the size of the determination coefficient of 0.657, it explains that the contribution of the aspects of leadership, communication and work discipline to employee performance is $65.7 \%$. While the rest (residual value) of the role of the variables not examined was $34.3 \%$, indicating that there are other factors that can affect the performance variable.

\section{Pendahuluan (Introduction)}

Manajemen sumber daya manusia dalam organisasi sangatlah penting, karena hal tersebut merupakan pemeran utama pendayagunaan sumber-sumber yang lain. Bagaimanapun lengkapnya sarana dan fasilitas kerja semuanya tidak berarti tanpa ditunjang sumber daya manusia yang ada seperti pegawai yang terampil dan mempunyai dedikasi tinggi dari masing-masing anggota organisasi. Seorang pegawai yang memiliki dedikasi yang tinggi ditunjukkan dengan kinerja (hasil kerja atau karya yang dihasilkan) yang tinggi dan baik dalam mencapai tujuan dan sasaran yang telah ditetapkan oleh organisasi.

Kepemimpinan dalam suatu organisasi mempunyai dampak cukup luas termasuk perilaku pegawai, kepemimpinan yang mampu menggerakkan pegawai kemungkinan dapat meningkatkan kinerja pegawai. Namun, sebaliknya kepemimpinan yang tidak mendapat dukungan dari pegawai kemungkinan pegawai akan bekerja dengan malas karena rasa kurang simpati kepada pemimpin. Pemimpin yang baik berupaya meningkatkan kinerja pegawainya.

Berdasarkan pengamatan sementara peneliti, di Dinas Pendidikan, Pemuda dan Olahraga Kabupaten Bireuen peran Kepemimpinanya kurang maksimal. Sebagai seorang pemimpin hendaknya menggunakan kewenangannya dengan baik. Hal ini sejalan dengan yang diungkapkan Heidjrachman (2007:217) bahwa pimpinan adalah seseorang yang mempunyai wewenang untuk memerintah orang lain dan didalam mengerjakan pekerjaannya untuk mencapai tujuan yang telah ditetapkan dengan bantuan orang lain. 
Sementara itu yang terjadi di Dinas Pendidikan, Pemuda dan Olahraga Kabupaten Bireuen, pemimpin tidak menggunakan kewenangannya dengan baik. Hal tersebut terlihat dengan adanya pembagian tugas yang tidak merata. Masih dijumpai pegawai yang mempunyai kinerja rendah dibiarkan tanpa mendapat teguran atau sanksi tegas. Sementara itu ada pegawai yang diberi tugas dan tanggung jawab banyak menjadi kurang fokus terhadap pekerjaan yang diberikan pimpinan. Akibatnya pegawai bekerja tidak sesuai dengan tugas dan tanggungjawabnya, sehingga dapat berpengaruh terhadap kinerja pegawai.

Dengan adanya hal tersebut, komunikasi sangat dibutuhkan antara pegawai dengan pimpinan maupun antara sesama pegawai. Komunikasi dipandang sebagai suatu proses yang perananya sangat besar, karena komunikasi yang terjadi didalam suatu organisasi nantinya juga akan mempengaruhi kegiatan organisasi, seperti efisiensi kerja, kepuasan pegawai dan lainnya. Komunikasi memberikan penjelasan kepada para pegawai tentang apa yang harus dilakukan, seberapa baik pegawai mengerjakannya dan apa yang dapat dilakukan untuk meningkatkan kinerja jika sedang berada di bawah standar. Apabila terjadi kesalahan dan hambatan yang terjadi dalam komunikasi akan menyebabkan kinerja organisasi terhambat, begitu juga sebaliknya.

Pada Dinas Pendidikan, Pemuda dan Olahraga Kabupaten Bireuen, komunikasi yang terjadi haruslah efektif sehingga arus pesan yang disampaikan diantara pegawai dapat diterima. Akan tetapi dalam menjalankan komunikasi yang efektif di Dinas Pendidikan, Pemuda dan Olahraga Kabupaten Bireuen kadangkala ditemui kendala, diduga perbedaan informasi dalam penerimaan pesan dan kurang tercapainya kesamaan makna menjadi penyebabnya. Pegawai terkadang tidak seluruhnya memahami tugas yang harus dilaksanakan dan pegawai kadang kala keliru menafsirkan informasi yang disampaikan dalam menjalankan intruksi pimpinan.

Komunikasi yang berjalan baik disuatu organisasi bukan hanya dapat meningkatkan baik itu hubungan antar sesama pegawai tapi juga lebih dari itu yakni dapat meningkatkan silahturahmi antar sesama manusia. Didalam organisasi, komunikasi sangat diperlukan untuk mengeluarkan pendapat, melihat karakter pegawai, dan masih banyak lagi yang berguna dalam peningkatan kinerja organisasi. Apabila komunikasi dalam penyampaiannya baik atau tidak didalam suatu organisasi maka budaya didalam organisasi tersebut dapat dilihat apakah teratur dengan baik tidaknya juga dalam tingkat kedisiplinan pegawai, cara kerja pegawai, serta kinerja pegawai.

Disiplin sangat penting artinya bagi kehidupan manusia, karena disiplin harus ditanamkan secara terusmenerus agar disiplin menjadi kebiasaan. Orangorang yang berhasil dalam bidang pekerjaan, umumnya mempunyai kedisiplinan yang tinggi, sebaliknya orang yang gagal umumnya tidak disiplin. Disiplin merupakan sutau proses latihan dan belajar untuk meningkatkan kemampuan dalam bertindak, berfikir dan bekerja yang aktif dan kreatif. Disiplin juga merupakan suatu kepatuhan dari orang-orang dalam suatu organisasi terhadap peraturan-peraturan yang telah ditetapkan sehingga menimbulkan keadaan tertib (Fauzi, 2009:1).

Permasalahan Kedisiplinan khususnya Kedisiplinan Pegawai Negeri Sipil, hingga saat ini masih mendapat sorotan yang tajam dari masyarakat. Sebagai contoh yang banyak dilansir media massa baik cetak maupun elektronik, menyebutkan adanya PNS meninggalkan tempat tugas tanpa ijin pimpinan. Berbagai sangsi terhadap pegawai yang terkena razia penegakan disiplin telah dikenakan sangsi kedisiplinan. Pelanggaran maupun permasalahan kedisiplinan pegawai telah menghambat fungsi pelayanan pemerintah akibat adanya oknum PNS yang tidak menjalankan tugasnya secara optimal.

Mengingat betapa pentingnya kepemimpinan, komunikasi dan disiplin kerja terhadap kinerja pegawai, penulis tertarik untuk melakukan penelitian dalam bentuk skripsi dengan judul "Pengaruh Kepemimpinan, Komunikasi dan Disiplin Kerja Terhadap Kinerja Pegawai Dinas Pendidikan, Pemuda dan Olahraga Kabupaten Bireuen".

\section{Tinjauan Literatur (Literature Review)}

\section{a. Pengaruh Kepemimpinan terhadap Kinerja Pegawai}

Menurut Teori Michigen, dalam Robin (2003: 44), menyatakan: "Bahwa pemimpin yang berorientasi karyawan memiliki pengaruh terhadap kinerja kelompok kerja". Dalam teori Jalur Tujuan, Robin (2003: 55) Menggambarkan; 1) Kepemimpinan yang suportif menghasilkan kinerja dan kepuasan pegawai yang tinggi bila bawahan mengerjakan tugas terstruktur. 2) Kepemimpinan yang berorientasi prestasi akan meningkatkan pengharapan bawahan bahwa upaya akan mendorong kinerja yang tinggi bila tugas-tugas terstruktur. 
Keberhasilan suatu lembaga atau instansi baik sebagai keseluruhan maupun berbagai kelompok dalam suatu lembaga atau instansi tertentu, sangat tergantung pada efektivitas kepemimpinan yang terdapat dalam lembaga atau instansi yang bersangkutan. Dapat dikatakan bahwa mutu kepemimpinan yang terdapat dalam suatu lembaga atau instansi memainkan peranan yang sangat dominan dalam keberhasilan lembaga atau instansi tersebut dalam menyelenggarakan berbagai kegiatannya terutama terlihat dalam kinerja para pegawainya (Siagian, 2006).

Pemimpin yang terdapat pada lembaga atau instansi harus memiliki kelebihan-kelebihan dibandingkan dengan bawahannya, yaitu pegawai yang terdapat di lembaga atau instansi yang bersangkutan, sehingga dapat menunjukkan kepada bawahannya untuk bergerak, bergiat, berdaya upaya yang tinggi untuk mencapai tujuan-tujuan yang telah ditetapkan. Akan tetapi hanya mengerahkan seluruh pegawai saja tidak cukup, sehingga perlu adanya suatu dorongan agar para pegawainya mempunyai minat yang besar terhadap pekerjaanya. Atas dasar inilah selama perhatian pemimpin diarahkan kepada bawahannya, maka kinerja pegawainya akan tinggi.

\section{b.Pengaruh Komunikasi terhadap Kinerja Pegawai}

Salah satu prinsip dalam manajemen dan organisasi adalah kerja sama. Kerjasama dapat dilaksanakan dengan baik apabila terjadi komunikasi dialogis antara manajer dan bawahan dan diantara seluruh pekerja yang melaksanakan kegiatan organisasi (Athoillah, 2010). Dengan adanya respons, anggapan atau umpan balik yang diberikan oleh komunikan berarti pesan yang dikirim itu sudah sampai sehingga terjadi komunikasi dua arah (Athoillah, 2010).

Sebuah organisasi atau instansi tentu harus memiliki pola komunikasi organisasi dalam instansi, agar instansi yang dipimpin dapat berjalan dengan baik dan bisa mencapai tujuan. Dimana yang di maksud pola komunikasi adalah bentuk atau pola hubungan antara dua orang atau lebih dalam proses penerimaan pesan yang mengaitkan dua komponen, yaitu gambaran atau rencana yang meliputi langlah-langkah pada suatu aktifitas dengan komponen-komponen yang merupakan bagian penting atas terjadinya hubungan komunikasi antar manusia atau kelompok dan organisasi. Dinas Pendidikan, Pemuda dan Olahraga Kabupaten Bireuen khususnya dalam satuan kerja Procurement \& Material Management menggunakan pola komunikasi rantai

Bentuk komunikasi yang dilakukan secara formal dan bertahap. Ada beberapa tingkat jabatan dalam struktur Organisasi, Jabatan tertinggi dari Kepala Dinas ke Sekretaris dan Sub bagian/seksi-seksi dan pembantu umum. Jika penyampaian informasi dari sub bagian atau seksi-seksi harus melalui proses dari tingkat jabatan yang rendah sampai tertinggi, tidak boleh langsung ke Kepala Dinas dan proses penyampaian informasi itu melalui rapat. Data yang ditemukan dilapangan mengungkapkan bahwa, pola komunikasi yang dilakukan antara pimpinan dengan pegawai ada dua yaitu, secara formal dan secara struktural.

Menurut Dewi (2007:9), Komunikasi adalah suatu pertukaran, proses simbolik yang menghendaki orangorang agar mengatur lingkungannya dengan membangun hubungan antar sesama manusia melalui pertukaran informasi untuk mengkuatkan sikap dan tingkah laku orang lain, serta berusaha mengubah sikap dan tingkah laku itu. Sedangkan Himstreet dan Baty dalam Purwanto (2006:3), menyatakan bahwa komunikasi adalah suatu proses pertukaran informasi antar individu melalui suatu sistem yang biasa (lazim) baik dengan simbol-simbol, sinyal- sinyal, maupun perilaku atau tindakan.

Menurut Dewi dalam Halim (2012:52), kinerja yang tinggi dapat didukung oleh komunikasi yang efektif, bagaimana karyawan berinteraksi, menyampaikan informasi, bertukar gagasan, baik antara atasan ke bawahan maupun sebaliknya, antara karyawan dengan karyawan, maupun karyawan pada satu bagian ke bagian lainnya. Proses koumunikasi adalah pemindahan pengertian dalam bentuk gagasan atau informasi dari satu orang ke orang lain lebih dari sekedar kata-kata yang digunakan dalam percakapan tetapi juga ekspresi wajah, intonasi, vokal dan sebagainya. Proses komunikasi yang begitu dinamik dapat menimbulkan berbagai masalah yang mempengaruhi pencapaian sebuah organisasi.

\section{c. Pengaruh Disiplin Kerja terhadap Kinerja Pegawai}

Disiplin yang baik mencerminkan besarnya rasa tanggung jawab seseorang terhadap tugas-tugas yang diberikan kepadanya. Hal ini mendorong gairah kerja, semangat kerja dan terwujudnya tujuan perusahaan dan pegawainya. Oleh karena itu pimpinan selalu berusaha agar bawahannya selalu mempunyai disiplin yang baik. Seorang pemimpin dikatakan efektif dalam kepemimpinannya, jika bawahannya berdisplin baik. Untuk memelihara dan meningkatkan kedisiplinan yang baik adalah hal yang sulit, karena banyak faktor mempengaruhinya. Kedisiplinan harus ditegakkan dalam suatu organisasi perusahaan. Tanpa dukungan 
disiplin pegawai yang baik, lembaga atau instansi sulit untuk mewujudkan tujuannya yaitu pencapaian kinerja optimal pegawai. Jadi, disiplin adalah kunci keberhasilan suatu perusahaan dalam mencapai tujuannya (Hasibuan, 2001:194). Sedangkan Singodimendjo dalam Edi Sutrisno (2011:96) menyatakan bahwa: "Semakin baik disiplin kerja seorang pegawai/karyawan, maka semakin tinggi hasil kerja (kinerja) yang akan dicapai"

Disiplin merupakan tindakan manajemen untuk mendorong para anggota organisasi guna memenuhi berbagai ketentuan.Dalam penerapannya, disiplin lebih ditekankan pada unsur kesadaran individu untuk mengikuti peraturan- peraturan yang berlaku dalam organisasi (Susilaningsih, 2008: 3). Penelitian yang dilakukan oleh Raharjo (2012: 7) yang menunjukkan bahwa variabel disiplin kerja berpengaruh terhadap variabel kinerja pegawai. Dalam hal ini, kedisiplinan penting bagi organisasi sebab akan ditaati oleh sebagian besar pegawai dan diharapkan pekerjaan akan dilakukan secara efektif. Penerapan disiplin bagi karyawan diharapkan dapat meningkatkan kinerja karyawan. Disamping itu perlu didukung lingkungan kerja yang baik berupa lingkungan kerja yang dapat menunjang kelancaran, keamanan, keselamatan, kebersihan, serta kenyamanan dalam bekerja dan adanya fasilitas yang memadai sehingga karyawan merasa aman, tenang dan senang dalam menjalankan tugas- tugas yang dibebankan dan menjadi tanggung jawabnya (Suprayitno 2007: 24).

Berdasarkan uraian di atas penulis dapat menggambarkan kerangka pemikiran sebagai berikut :

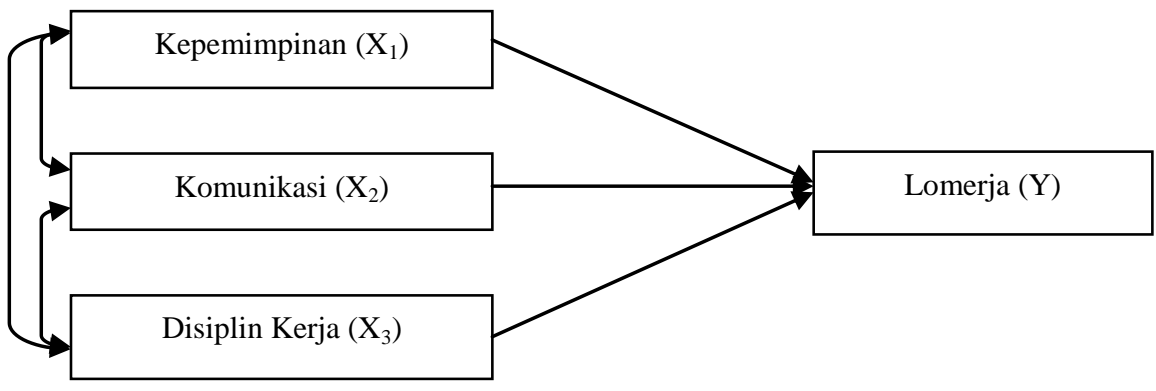

Gambar 1. Kerangka Pemikiran

\section{Metode Penelitian (Methodology)}

\section{a. Metode dan Variabel Penelitian}

Metode penetian yang akan digunakan dalam penelitian ini adalah metode asosiatif dengan pendekatan kuantitatif. Metode asosiatif merupakan metode yang bermaksud untuk menjelaskan hubungan kausal dan pengaruh antara variabel-variabel melalui pengujian hipotesis. Menurut Sugiyono (2012:11) menyatakan bahwa pengertian asosiatif adalah Penelitian yang bertujuan untuk mengetahui pengaruh ataupun hubungan antara dua variabel atau lebih.

Adapun variabel, dimensi dan indikator pengukurnya di definisikan berikut ini.

Tabel 1. Operasional Variabel Penelitian

\begin{tabular}{|c|c|c|}
\hline Variabel & Defenisi Konsep & Indikator \\
\hline $\begin{array}{l}\text { Kepemimpinan } \\
\left(\mathrm{X}_{1}\right)\end{array}$ & $\begin{array}{l}\text { Kepemimpinan adalah proses mempengaruhi atau memberi } \\
\text { contoh kepada pengikut-pengikutnya lewat proses komunikasi } \\
\text { dalam upaya mencapai tujuan organisasi. Keseluruhan } \\
\text { tindakan guna mempengaruhi serta menggiatkan orang dalam } \\
\text { usaha bersama untuk mencapai tujuan, atau dengan definisi } \\
\text { yang lebih lengkap dapat dikatakan bahwa kepemimpinan } \\
\text { adalah proses pemberian jalan yang mudah dari pada } \\
\text { pekerjaan orang lain yang terorganisir dalam organisasi } \\
\text { formal guna mencapai tujuan yang telah ditetapkan. } \\
\text { Rivai }(2007: 2) \text { Thoha }(2010: 9)\end{array}$ & $\begin{array}{l}\text { a. Inovator } \\
\text { b. Komunikator } \\
\text { c. Motivator } \\
\text { d. Kontroler } \\
\text { Thoha }(2010: 52)\end{array}$ \\
\hline $\begin{array}{l}\text { Komunikasi } \\
\left(\mathrm{X}_{2}\right)\end{array}$ & $\begin{array}{l}\text { Komunikasi merupakan proses penyampaian suatu pesan } \\
\text { dalam bentuk lambang bermakna sebagai pikiran dan perasaan } \\
\text { berupa ide, informasi, kepercayaan, harapan, himbauan, dan } \\
\text { sebagai panduan yang dilakukan oleh seseorang kepada orang } \\
\text { lain, baik langsung secara tatap muka maupun tidak langsung } \\
\text { melalui media, dengan tujuan mengubah sikap, pandangan }\end{array}$ & $\begin{array}{l}\text { a. Kemudahan perolehan } \\
\text { informasi } \\
\text { b. Kualitas media } \\
\text { c. Muatan informasi } \\
\text { Rogers }(2008: 20)\end{array}$ \\
\hline
\end{tabular}




\begin{tabular}{|c|c|c|}
\hline & atau prilaku. Effendy (2007:60) & \\
\hline $\begin{array}{l}\text { Disiplin kerja } \\
\left(\mathrm{X}_{3}\right)\end{array}$ & $\begin{array}{l}\text { Disiplin kerja adalah kesadaran dan kerelaan seseorang dalam } \\
\text { menaati semua peraturan perusahaan dan norma-norma sosial } \\
\text { yang berlaku. (Hasibuan, 2006:444). } \\
\text { Disiplin kerja adalah suatu alat yang dipergunakan para } \\
\text { manajer untuk berkomunikasi dengan pegawai agar mereka } \\
\text { bersedia untuk mengubah suatu perilaku serta sebagai suatu } \\
\text { upaya untuk meningkatkan kesadaran dan kesedian seorang } \\
\text { dalam memenuhi segala peraturan perusahaan. } \\
\text { (Rivai, 2011:825) }\end{array}$ & $\begin{array}{l}\text { a. Kehadiran } \\
\text { b. Taat Peraturan } \\
\text { c. Norma } \\
\text { Dharmawan }(2011: 15)\end{array}$ \\
\hline $\begin{array}{l}\text { Kinerja } \\
(\mathrm{Y})\end{array}$ & $\begin{array}{l}\text { Kinerja (performance) adalah hasil kerja yang dapat dicapai } \\
\text { oleh seseorang atau kelompok orang dalam suatu organisasi } \\
\text { sesuai dengan wewenang masing-masing dalam upaya } \\
\text { pencapaian tujuan organisasi secara legal, tidak melanggar } \\
\text { hukum, sesuai dengan moral dan etika. (Sudarmayanti, } \\
2008: 147 \text { ) }\end{array}$ & $\begin{array}{l}\text { a. Sasaran Kerja Pegawai } \\
\text { (SKP) } \\
\text { b. Perilaku Kerja }\end{array}$ \\
\hline
\end{tabular}

\section{b. Populasi dan Sampel Penelitian}

Populasi yang akan diteliti dalam penelitian ini adalah seluruh Pegawai Negeri Dinas Pendidikan, Pemuda dan Olahraga Kabupaten Bireuen yang berjumlah 78 orang. Karena jumlah populasi terbatas, maka smua unit populasi untuk dipilih sebagai anggota sampel.

\section{c. Metode Analisis}

Metode analisis data menggunakan pendekatan Analisis Jalur (Path Analysis). Analisis jalur digunakan untuk mengetahui besarnya pengaruh suatu variabel terhadap variabel lainnya baik pengaruh langsung maupun tidak langsung. Langkah dalam melakukan analisis data dengan menggunakan analisis jalur sesuai dengan modifikasi dari Harun dalam Nirwana (2014:19-28). Besarnya pengaruh variabel bebas terhadap variabel terikat disebut koefisien jalur.

Menurut Pedhazur (1982) dalam Marwan Hamid, dkk (2019), bahwa tujuan analisis jalur adalah apakah model yang diusulkan cocok atau tidak dengan data, yaitu dengan cara membandingkan matriks korelasi teoritis dengan matriks korelasi empiris. Jika kedua matriks relatif sama, maka model dikatakan "cocok" atau fit.

Analisis jalur ialah suatu teknik untuk menganalisis hubungan sebab-akibat yang terjadi pada regresi berganda jika variabel bebasnya mempengaruhi variabel tergantungnya tidak hanya secara langsung, tetapi juga secara tidak langsung" (Robert D. Rutherford, 1993, dalam Marwan Hamid, dkk; 2019:10). Definisi lain mengatakan "Analisis jalur merupakan pengembangan langsung bentuk regresi berganda dengan tujuan untuk memberikan estimasi tingkat kepentingan (magnitude) dan signifikansi (significance) hubungan sebab-akibat hipotetikal dalam seperangkat variabel" (Paul Webley; 1997)

Menurut Marwan Hamid, dkk (2019:10), Model analisis jalur digunakan untuk menganalisis pola hubungan antar variabel dengan tujuan untuk mengetahui pengaruh langsung maupun tidak langsung seperangkat variabel bebas (eksogen) terhadap variabel terikat (endogen). Model analisis jalur yang dibicarakan adalah pola hubungan sebab-akibat.

Analisis jalur ini mengikuti pola struktural atau disebut model struktural. Model struktural secara umum dapat digambarkan dengan persamaan sebagai berikut : $\mathrm{Y}=f\left(\mathrm{X}_{1}, \mathrm{X}_{2}, \mathrm{X}_{3}\right)$. Diagram jalur dan persamaan struktural penelitian ini adalah seperti terlihat pada Gambar 1 berikut :
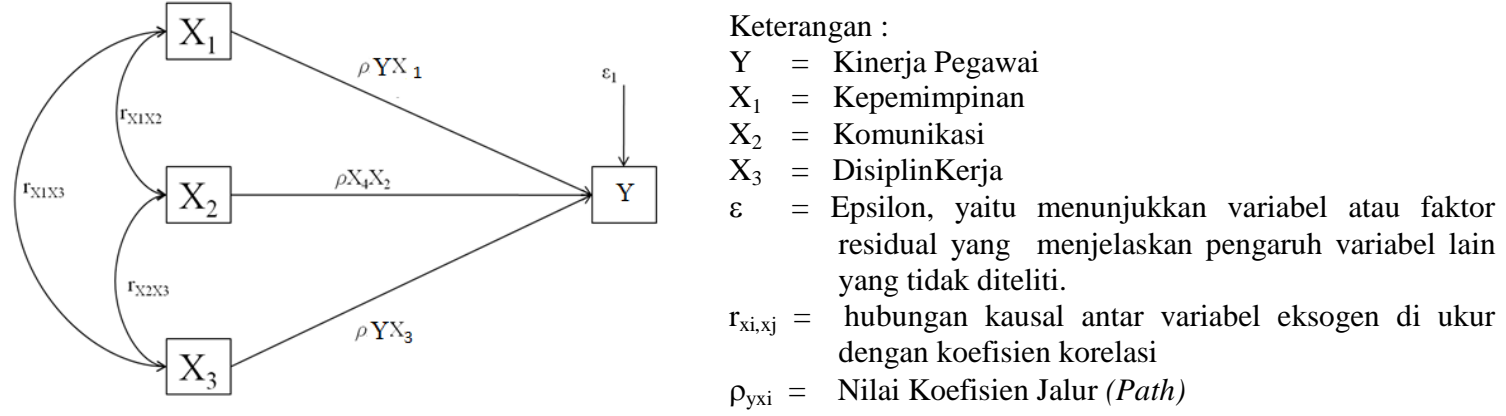
residual yang menjelaskan pengaruh variabel lain yang tidak diteliti.

$\mathrm{r}_{\mathrm{xi}, \mathrm{xj}}=$ hubungan kausal antar variabel eksogen di ukur dengan koefisien korelasi

$\rho_{\mathrm{yxi}}=$ Nilai Koefisien Jalur $($ Path $)$

Gambar 1 Diagram Jalur Penelitian 


\section{Hasil dan Pembahasan (Results and Discussion)}

\section{a. Karakteristik Responden}

Responden penelitian adalah semua pegawai pada Dinas Pendidikan, Pemuda dan Olahraga Kabupaten Bireuen diketahui responden berjenis kelamin laki-laki sebanyak 47 orang atau $60,3 \%$ dan responden yang berjenis kelamin perempuan sebanyak 31 orang atau 39,7\%.Jumlah responden berdasarkan pendidikan terakhir pada tingkat SMA berjumlah tidak ada, untuk tingkat pendidikkan Diploma berjumlah 20 orang atau 17,4\%, sedangkan pada tingkat pendidikan Sarjana (S1) berjumlah 87 orang atau 75,7\%, pada jenjang pendidikan Pascasarjana (S2) berjumlah 8 orang atau 7,0\%.

Pegawai yang berumur 18-25 tahun sebanyak 11 orang atau $14,1 \%$, responden yang berumur 26-35 tahun sebanyak 23 orang atau $29,5 \%$, sedangkan responden yang berumur 36-45 tahun sebanyak 31 orang atau $39,7 \%$, sedangkan responden yang berumur $>45$ tahun sebanyak 13 orang atau $16,7 \%$.

Jumlah pegawai berdasarkan pendidikan terakhir pada tingkat SMA berjumlah 22 orang atau $28,2 \%$ dari jumlah, untuk tingkat pendidikkan Diploma berjumlah 9 orang atau $11,5 \%$, sedangkan pada tingkat pendidikan Sarjana (S1) berjumlah 40 orang atau 51,3\%, pada jenjang pendidikan Pascasarjana (S2) berjumlah 7 orang atau $9,0 \%$.

\section{b. Hasil analisis Deskriptif}

Secara deskriptif akan diukur persepsi pegawai tentang varibel yang diteliti sehingga mendapatkan gambaran mengenai suatu data yang akan diteliti atau untuk menguraikan kecenderungan jawaban responden dari tiap-tiap variabel. Berdasarkan hasil kuesioner yang telah teruji validitas dan reliabilitasnya, dari 78 pegawai, diperoleh deskripsi setiap variabel yang diteliti, sebagai berikut.

Tabel 2. Deskripsi Pegawai tentang Variabel Penelitian

\begin{tabular}{|c|c|c|c|c|c|c|}
\hline \multirow{2}{*}{ Variabel } & \multicolumn{5}{|c|}{ Persentase Jawaban } & \multirow{2}{*}{$\begin{array}{c}\text { Skor } \\
\text { Pencapaian }\end{array}$} \\
\hline & SS & $\mathbf{S}$ & KS & TS & STS & \\
\hline 1. Kepemimpinan & 11.00 & 36.09 & 43.47 & 9.44 & 0.00 & $69,97 \%$ \\
\hline 2. Komunikasi & 12.62 & 36.12 & 44.64 & 6.62 & 0.00 & $71,89 \%$ \\
\hline 3. Disiplin kerja & 37.91 & 44.54 & 16.39 & 2.81 & 0.00 & $81,79 \%$ \\
\hline
\end{tabular}

Sumber : Hasil Peneltian, 2020 (data diolah, dengan SPSS)

Catatan : SS = Sangat setuju, $S=$ Setuju, KS = Kurang setuju, $T S=$ Tidak setuju $S T S=$ Sangat tidak setuju)

Berdasarkan tabel di atas dapat dijelaskan bahwa :

1) Faktor Kepemimpinan, menurut persepsi pegawai belum menunjukkan harapan yang baik dalam mendukung kinerja pegawai. Skor penilaian atas Kepemimpinan Kepala Sekolah baru mencapai 69,97\%

2) Faktor komunikasi yang terjalin dari pimpinan dengan bawahan dan antar pegawai, belum sesuai ekspektasi, baru mencapai 71,89 dari kondisi yang ideal,

3) Faktor kedisiplinan kerja pegawai dalam meningkatkan kinerja sudah baik, mencapai 81,79\%,

\section{c. Hasil Analisis Jalur}

Dalam penelitian ini model analisis dengan analisi jalur yang menentukan pengaruh Kepemimpinan , komunikasi dan disiplin kerja terhadap kinerja pegawai. Dengan model $Y=f(X 1, X 2, X 3)=\rho_{1} X_{1}+\rho_{2} X_{2}+$ $\rho_{3} X_{3}+$ e. Adapun pembuktian hipotesis secara simultan dapat dilihat pada tabel berikut ini:

Tabel 3. Uji Model Sruktural (Uji Secara Simultan)

\begin{tabular}{|l|l|r|r|r|r|r|}
\hline \multicolumn{1}{|l|}{ Model } & Sum of Squares & df & Mean Square & F & \multicolumn{1}{c|}{ Sig. } \\
\hline & Regression & 777.931 & 3 & 259.780 & 58.199 & $.000^{\mathrm{a}}$ \\
\hline Residual & 406.196 & 74 & 4.464 & & \\
\hline Total & 1185.858 & 77 & & & \\
\hline
\end{tabular}

a. Predictors: (Constant), Disiplin kerja, Komunikasi, Kepemimpinan

b. Dependent Variable: Kinerja

Sumber: Data olahan, 2020 (diolah dengan SPSS)

Berdasarkan hasil uji $F$ diperoleh nilai $F_{\text {hitung }}$ sebesar 58,199. Sementara nilai signifikansinya 0,000. Hal ini menunjukkan model regresi antar variabel signifikansi linier. Maka model analisi jalur dalam bentuk $\mathrm{Y}=$ $f(X 1, X 2, X 3)=\rho_{1} X_{1}+\rho_{2} X_{2}+\rho_{3} X_{3}$ diterima. 


\section{1). Pengujian Hipotesis Penelitian}

Dalam hal ini hipotesis yang diajukan selanjutnya diuji untuk menjawab masalah penelitian yang dirumuskan, yakni:

Hasil pengolahan data dalam menaksir koefisiein jalur dan uji signifikansinya;

Tabel 4. Taksiran Koefisien Jalur Variabel Bebas (Eksogenus) dan Uji-t

\begin{tabular}{|l|c|c|c|}
\hline \multirow{2}{*}{ Model } & Unstandardized Coefficients & t & \multirow{2}{*}{ Sig. } \\
\cline { 2 - 2 } Kepemimpinan & Beta & & \\
\hline Komunikasi & 0.293 & 2.928 & 0.004 \\
\hline Disiplin Kerja & 0.296 & 3.175 & 0.002 \\
\hline
\end{tabular}

a. Dependent Variable: Kinerja

Uji hipotesis:

Hipotesis-1:

Ho: $\rho_{z x 1} \leq 0$ : Kepemimpinan tidak berpengaruh terhadap Kinerja pegawai

$\mathrm{H}_{1}: \rho_{\mathrm{zx} 1}>0$ : Kepemimpinan berpengaruh terhadap Kinerja pegawai

Kriteria pengujian adalah total Ho jika $t_{\text {hitung }}>t_{\text {tabel }}$ dimana $t_{\text {tabel }}$ untuk $\alpha=5 \%$ adalah 1,992 . Hipotesis ini menyatakan ada pengaruh Kepemimpinan $\left(\mathrm{X}_{1}\right)$ terhadap Kinerja pegawai $(\mathrm{Y})$. Dengan koefisien jalurnya $\rho_{\mathrm{yx} 1}=0,293$. Hasil perhitungan uji individu menunjukkan harga $\mathrm{t}_{\text {hitung }}$ sebesar 2,928. Dengan demikian $\mathrm{t}_{\text {hitung }}$ $>t_{\text {tabel }}(2,029>1,992)$. Sehingga $H_{1}$ diterima artinya koefisien jalur Kepemimpinan $\left(X_{1}\right)$ terhadap Kinerja pegawai (Y) dapat dinyatakan signifikan pada taraf signifikan $\alpha=0,05$.

Hipotesis 2

Ho: $\rho_{\mathrm{yx} 2} \leq 0$ : Komunikasi tidak berpengaruh terhadap Kinerja pegawai

$\mathrm{H}_{1}: \rho_{\mathrm{yx} 2}>0$ : Komunikasi berpengaruh terhadap Kinerja pegawai

Hipotesis ini menyatakan ada pengaruh komunikasi $\left(\mathrm{X}_{2}\right)$ terhadap Kinerja pegawai $(\mathrm{Y})$. Dengan koefisien jalurnya $\rho_{\mathrm{yx} 2}=0,296$. Hasil perhitungan uji individu menunjukkan harga $\mathrm{t}_{\text {hitung }}$ sebesar 3,175 Dengan demikian $t_{\text {hitung }}>t_{\text {tabel }}(3,175>1,982)$. Sehingga $H_{1}$ diterima, yang artinya koefisien jalur variabel Komunikasi $\left(\mathrm{X}_{2}\right)$ berpengaruh terhadap Kinerja pegawai $(\mathrm{Y})$.

Hipotesis 3

Ho: $\rho_{\text {yzz }} \leq 0$ : Disiplin kerja tidak berpengaruh terhadap Kinerja pegawai

$\mathrm{H}_{1}: \rho_{\mathrm{yx} 3}>0$ : Disiplin kerja berpengaruh terhadap Kinerja pegawai

Hipotesis ini menyatakan ada pengaruh Disiplin kerja berpengaruh terhadap Kinerja pegawai (Y). Dengan koefisien jalurnya $\rho_{\mathrm{zyx} 3}=0,315$. Hasil perhitungan uji individu menunjukkan harga $\mathrm{t}_{\text {hitung }}$ sebesar 3,367. Dengan demikian $t_{\text {hitung }}>t_{\text {tabel }}(3,367>1,992)$. Sehingga $H_{1}$ diterima artinya koefisien jalur variabel Disiplin kerja $\left(\mathrm{X}_{3}\right)$ berpengaruh terhadap Kinerja pegawai $(\mathrm{Y})$, secara signifikan pada taraf uji $\alpha=0,05$.

\section{2). Menentukan Model Struktural}

Setelah terbukti adanya hubungan dan pengaruh secara signifikans anatara variabel eksogen terhadap variabel endogen dalam penelitian ini, lalu dilakukan taksiran nilai kausalitas antar variabel eksogen $\left(\mathrm{X}_{1}\right.$, $\mathrm{X}_{2}, \mathrm{X}_{3}$ ) pada tabel 5, dan taksiran koefisien jalur pada tabel 5, yakni :

Tabel 5. Hubungan Kausal Antar Variabel Bebas (Eksogenus)

\begin{tabular}{|l|l|c|c|c|}
\hline & & Kepemimpinan & Komunikasi & Disiplin Kerja \\
\hline \multirow{5}{*}{ Kepemimpinan } & Pearson Correlation & 1 & $.570^{* *}$ & 0.677 \\
\cline { 2 - 5 } & Sig. (2-tailed) & & 0 & 0 \\
\cline { 2 - 5 } & $\mathrm{N}$ & 78 & 78 & 78 \\
\hline \multirow{5}{*}{ Komunikasi } & Pearson Correlation & $.570^{* *}$ & 1 & 0.788 \\
\cline { 2 - 5 } & Sig. (2-tailed) & 0 & & 0 \\
\cline { 2 - 5 } & $\mathrm{N}$ & 78 & 78 & 78 \\
\hline & Pearson Correlation & 0.677 & 0.788 & 1 \\
\cline { 2 - 5 } & Sig. (2-tailed) & 0 & 0 & 78 \\
\cline { 2 - 5 } & $\mathrm{N}$ & 78 & 78 & \\
\hline
\end{tabular}

**. Correlation is significant at the 0.01 level (2-tailed). 
Berdasarkan antar variabel eksogen, dan nilai koefisien jalur $(\rho)$, maka model kausal yang dibentuk secara teoritik diperoleh diagram jalur seperti gambar 2.

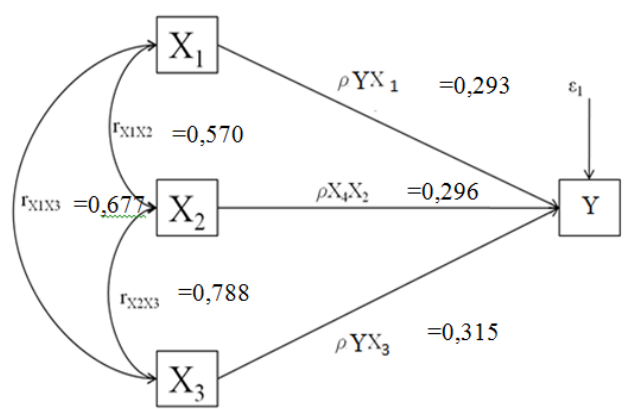

Gambar 2. Diagram Jalur Penelitian

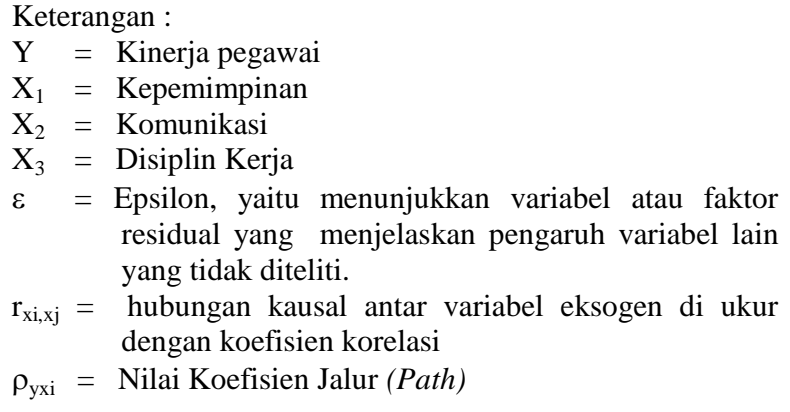

Keterangan :

$\mathrm{X}_{2}=$ Komunikasi

$\mathrm{X}_{3}=$ Disiplin Kerja

residual vang menjelaskan pengaruh variabel lain yang tidak diteliti. dengan koefisien korelasi

\section{d. Pembahasan}

\section{1). Pengaruh Kepemimpinan terhadap Kinerja Pegawai}

Hasil analisis data sebelumnya, menunjukkan adanya pengaruh Kepemimpinan terhadap kinerja pegawai. Adapun besarnya pengaruh, langsung ataupun tidak langsung karena terdapat hubungan kausalitas antara variabel Kepemimpinan dengan komunikasi dan disiplin kerja, ditentukan berikut ini:

Besarnya pengaruh langsung Kepemimpinan $\left(\mathrm{X}_{1}\right)$ terhadap kinerja pegawai $(\mathrm{Y})$, dinyatakan dengan besaran koefisien jalur $\left(\rho_{\mathrm{zx} 1}=0,293\right)$, Sehingga besarnya pengaruh langsung ini adalah: 8,58 persen.

Besarnya pengaruh tak langsung Kepemimpinan $\left(\mathrm{X}_{1}\right)$ terhadap kinerja pegawai $(\mathrm{Y})$, karena adanya hubungan kausal dalam variabel eksogen, sehingga di hitung sebagai berikut:

- Pengaruh Kepemimpinan dan komunikasi terhadap kinerja pegawai, adalah: $(0,293)(0,570)(0,296) \mathrm{x}$ $100 \%=4,94 \%$

- Pengaruh Kepemimpinan dan disiplin kerja terhadap kinerja pegawai, adalah: $(0,293)(0,677)(0,296) \mathrm{x}$ $100 \%=5,33 \%$

Maka Pengaruh Total Kepemimpinan $\left(\mathrm{X}_{1}\right)$ terhadap kinerja pegawai adalah 18,85 persen.

\section{2). Pengaruh Komunikasi terhadap Kinerja pegawai}

Hasil analisis data sebelumnya, menunjukkan adanya pengaruh komunikasi terhadap kinerja pegawai. Adapun besarnya pengaruh langsung ataupun tidak langsung karena terdapat hubungan kausalitas antara variabel eksogen, ditentukan berikut ini:

Besarnya pengaruh langsung komunikasi $\left(\mathrm{X}_{2}\right)$ terhadap kinerja pegawai $(\mathrm{Y})$, dinyatakan dengan besaran koefisien jalur $\left(\rho_{\mathrm{yx} 2}=0,296\right)$, Sehingga besarnya pengaruh langsung ini adalah: $8,76 \%$.

Besarnya pengaruh tidak langsung:

- Pengaruh komunikasi dan Kepemimpinan terhadap kinerja pegawai, adalah: $(0,296)(0,570)(0,293) \mathrm{x}$ $100 \%=4,94 \%$

- Pengaruh komunikasi dengan disiplin kerja terhadap kinerja pegawai, adalah: $=(0,296)(0,788)(0,315) \mathrm{x}$ $100 \%=7,34 \%$..

Maka Pengaruh Total komunikasi $\left(\mathrm{X}_{2}\right)$ terhadap kinerja pegawai (Y) adalah 21,04 persen.

\section{3). Pengaruh Disiplin kerja terhadap Kinerja pegawai}

Hasil analisis data sebelumnya, menunjukkan adanya pengaruh disiplin kerja terhadap kinerja pegawai. Maka besarnya pengaruh langsung ataupun tak langsnung, ditentukan berikut ini:

Besarnya pengaruh langsung disiplin kerja terhadap kinerja pegawai dinyatakan dengan besaran koefisien jalur $\left(\rho_{\mathrm{yx} 3}=315\right)$, Sehingga besarnya pengaruh langsung ini adalah: $9,92 \%$.

- Pengaruh disiplin kerja dan Kepemimpinan terhadap kinerja pegawai, adalah: $(0,315)(0,677)(0,293) \mathrm{x}$ $100 \%=6,24 \%$

- Pengaruh disiplin kerja dan komunikasi terhadap kinerja pegawai, adalah: $(0,315)(0,788)(0,296) \times 100 \%$ $=7,34 \%$.

Maka pengaruh Total disiplin kerja $\left(\mathrm{X}_{3}\right)$ terhadap kinerja pegawai $(\mathrm{Y})$, adalah dengan 23,5 persen. 


\section{4). Pengaruh Kepemimpinan, Komunikasi dan Disiplin kerja terhadap Kinerja Pegawai}

Berdasarkan model struktural yang dikaji dan dibahas sebelumnya, maka dapat di perdalam dengan melibatkan ketiga faktor yang diduga berpengaruh pada kinerja pegawai, yakni faktor Kepemimpinan, komunikasi dan disiplin kerja terhadap kinerja pegawai secara simultan, yakni dengan menghitung korelasi dan determinasi antar variabel ini, yakni sebagai berikut:

a). Korelasi antar Kepemimpinan, komunikasi dan disiplin kerja terhadap kinerja pegawai secara simultan

Berdasarkan hitungan korelasi dan determinasi antar variabel Kepemimpinan, komunikasi dan disiplin kerja terhadap kinerja pegawai, sebagaimana ditunjukkan dalam tabel berikut :

Tabel 6. Korelasi dan Determinasi antar variabel

\begin{tabular}{|c|c|c|c|}
\hline $\mathrm{R}$ & R Square & Adjusted R Square & Std. Error of the Estimate \\
\hline $.811^{\mathrm{a}}$ & .657 & .646 & 2.113 \\
\hline
\end{tabular}

Maka dari informasi diatas, terdapat sebesar 0,811 korelasi antar variabel Kepemimpinan, komunikasi dan disiplin kerja terhadap kinerja pegawai. Ini menunjukkan hubungan yang kuat dengar derajat 0,811 dan hubungannya positip.

Dan Hasil koefsiein determinasinya $\left(\mathrm{R}^{2}\right)$ adalah sebesar 0,657 yang dimaknai bahwa terdapat sebesar 65,7 $\%$ kontribusi atau peranan adanya faktor Kepemimpinan, komunikasi dan disiplin kerja terhadap kinerja pegawai. Dan sisanya yakni sekitar $34,3 \%$ dipengaruhi oleh faktor lain, seperti kompensasi, fasilitas, Motivasi dan pelatihan, atau lainnya yang mengikat terhadap kinerja pegawai.

\section{Simpulan (Conclusion)}

Sebagaimana tujuan dari penelitian ini, maka dari hasil penelitian dan pembahasan yang dilakukan, dapat ditarik beberapa simpulan penting sebagai rangkuman dan temuan hasil penelitian, yakni:

a) Terdapat pengaruh langsung dan tidak langsung faktor kepemimpinan terhadap kinerja pegawai Dinas Pendidikan, Pemuda dan Olahraga Kabupaten Bireuen, yakni : 18,85 persen,

b) Terdapat pengaruh langsung dan tidak langsung faktor komunikasi terhadap kinerja pegawai pegawai Dinas Pendidikan, Pemuda dan Olahraga Kabupaten Bireuen yakni : 21,04 persen.

c) Terdapat pengaruh langsung dan tidak langsung aspek disiplin kerja terhadap kinerja pegawai pegawai Dinas Pendidikan, Pemuda dan Olahraga Kabupaten Bireuen, yakni : 23,5 persen

d) Berdasarkan ukuran koefisien determinasi sebesar 0,657 menjelaskan bahwa kontribusi aspek kepemimpinan, komunikasi dan disiplin kerja terhadap kinerja pegawai pegawai Dinas Pendidikan, Pemuda dan Olahraga Kabupaten Bireuen sebesar 65,7\%. Sementara sisanya (nilai residu) dari peran variabel yang tidak diteliti sebesar $34,3 \%$, menujukkan bahwa terdapat faktor-faktor lain yang dapat mempengaruhi variabel kinerja.

\section{DAFTAR PUSTAKA (References)}

1) Abdul Halim dkk, 2012. Akuntansi Sektor Publik Akuntansi Keuangan Daerah. Jakarta : Salemba Empat.

2) Athoillah, Anton. 2010. Dasar-dasar Manajemen. Bandung: CV Pustaka.

3) Dewi, Sutrisna. 2007. Komunikasi Bisnis. Edisi 1. Penerbit: C.V Andi Offset. Jakarta

4) Dharmawan. 2011. Lingkungan Kerja Fisik dan Non Fisik. PT. Remaja. Rosdakarya, Bandung

5) Edy, Sutrisno. 2011. Manajemen Sumber Daya Manusia. Penerbit: Jakarta,. Kencana.

6) Edy Sutrisno. 2014. Manajemen Sumber Daya Manusia. Cetak Ke Enam. Pranada Media Group. Jakarta.

7) Effendy, Onong Uchjana. 2007. Ilmu Komunikasi Teori dan Praktek, Bandung : PT. Remaja Rosdakarya.

8) Hasibuan, Malayu S.P. 2005. Manajemen Sumber Daya Manusia, Edisi Revisi. Bumi Aksara, Jakarta.

9) Heidjrachman Ranupandoyo dan Suad Husnan, 2007, Manajemen Personalia, edisi keempat, BPFe, Yogyakarta.

10) Marwan Hamid, Ibrahim Sufi, Win Konadi, dan Yusrizal Akmal, 2019. Analisis Jalur Dan Aplikasi Spss Versi 25, Edisi Pertama Sefa Bumi Persada, Medan.

11) Nirwana Sitepu, 2014. Analisis jalur, Unpad Bandung 
12) Purwanto, Ngalim. 2006. Psikologi Pendidikan. Bandung: PT Remaja Rosdakarya

13) Rivai, Veithzal. 2011. Manajemen Sumber Daya Manusia untuk Perusahaan, dari Teorike Praktik. Cetakan Pertama. PT. Raja Grafindo Persada, Jakarta.

14) Rivai, Veithzal. 2007. Manajemen Sumber Daya Manusia untuk Perusahaan, dari Teorike Praktik. PT. Raja Grafindo Persada, Jakarta.

15) Robbins SP, dan Judge. 2007. Perilaku Organisasi. Selemba Empat. Jakarta.

16) Robbins, Stephen, P, 2003, Prinsip-Prinsip Perilaku Organisasi. Erlangga. Jakarta.

17) Sedarmayanti. 2008. Sumber Daya Manusia dan Produktivitas Kerja. Bandung: CV. Mandar Maju Siagian, Sondang. P. 2006. Sistem Informasi Manajemen. Jakarta:PT. Bumi. Aksara).

18) Susilaningsih, Nur. 2008, Pengaruh Kepemimpinan, Disiplin, Motivasi, Pengawasan, dan Lingkungan Kerja Terhadap Kinerja Pegawai (Studi Pada Badan Perencanaan Pembangunan Daerah Kabupaten Wonogiri, EXCELENT, vol 1, no 2.

19) Suprayitno dan Sukir. 2007. Pengaruh Disiplin Kerja, Lingkungan Kerja dan Motivasi Kerja terhadap Kinerja Karyawan. Dalam Jurnal Manajemen Sumber Daya Manusia, Volume 2 N0. 1. Hal 23-24. Karanganyar: Universitas Slamet Riyadi Surakarta.

20) Thoha, Miftah.2010. Kepemimpinan Dalam Manajemen. Jakarta: PT. Raja. Grafindo Persada 